\title{
Surgical Management Strategies of Intracranial Arachnoid Cysts: A Single Institution Experience of 75 Cases
}

\author{
Intrakranial Araknoid Kistlerin Cerrahi Yönetim Stratejileri: \\ Bir Merkezin 75 Olguluk Tecrübesi
}

Bulent DUZ, Serdar KAYA, Mehmet DANEYEMEZ, Engin GONUL

Gulbane Military Medical Academy, Department of Neurosurgery, Ankara, Turkey

Correspondence address: Serdar KAYA / E-mail: drserdarkaya@gmail.com

\begin{abstract}
AIM: Arachnoid cysts are benign intra-arachnoid cystic lesions filled with cerebrospinal fluid. With advent of modern treatment techniques, debate continues regarding which surgical treatment is most effective.

MATERIAL and METHODS: A consecutive series of 75 patients with arachnoid cysts that were surgically treated between January 1992 and December 2009 are reported. Included in the study were 54 male and 21 female patients, ranging in age from 2 months to 45 years (mean age 20.02 years) at the time of surgery. Symptoms at presentation, location on the cysts, and treatment modalities were evaluated.

RESULTS: Headache was controlled in $92.5 \%$ of adult cases. Hydrocephalus, cognitive decline weakness and gait disturbances were controlled $100 \%$ after overall treatment methods. Follow-up CT scans showed significant reduction in cyst size in supratentorial arachnoid cysts. No significant changes in cyst size were found in infratentorial cysts but symptomatic improvements were noted.
\end{abstract}

CONCLUSION: Patients with symptomatic arachnoid cysts regardless of age and cyst location should be treated. We think that avoiding shunt dependence should be one of the principle treatment goals. Proper patient selection results in good outcomes.

KEYWORDS: Arachnoid cyst, Cystoventriculostomy, Cystocisternotomy, Cystoperitoneal shunt, Endoscopy

öz

AMAÇ: Araknoid kistler beyin omurilik sıvısıyla dolu benign intraaraknoidal kistik lezyonlardır. Yeni tedavi yöntemlerinin gelişmesiyle hangi cerrahi tedavinin en etkili olduğu yolundaki tartışmalar devam etmektedir.

YÖNTEM ve GEREÇLER: Ocak 1992 ile Aralık 2009 arasında cerrahi olarak tedavi edilen 75 ardışık olgu incelenmiştir. Çalışmaya katılanların 54'ü erkek, 21'i kadındı. Cerrahi sırasında yaşları 2 ayla 45 yaş arasında değişiyordu( ortalama 20,02 yıl). Ortaya çıkış belirtileri, kist yerleşimler ve tedavi şekilleri değerlendirildi.

BULGULAR: Erişkin olguların \%92,5'inde baş ağrısı kontrol altına alındı. Tüm tedavi şekilleri sonrasında hidrosefali, bilişsel bozulmalar ve yürüyüş bozuklukları \%100 kontrol altına alındı. Takip tomografi görüntüleri supratentorial kistlerin boyutunda belirgin azalma gösterdi. İnfratentorial kistlerde belirgin küçülme saptanmasa da klinik olarak belirgin düzelme kaydedildi.

SONUÇ: Semptomatik araknoid kisti olan olgular yaşına ve kist yerleşimine bakılmaksızın tedavi edilmelidirler. Şant bağımlıığını önlemek tedavinin prensiplerinden birisi olmalıdır. Doğru hasta seçimi tedavi yöntemlerinin başarısını artırmaktadır.

ANAHTAR SÖZCÜKLER: Araknoid kist, Kistoventrikülostomi, Kistosisternostomi, Kistoperitoneal şant, Endoskopi

\section{INTRODUCTION}

Arachnoid cysts are benign intra-arachnoidal cystic lesions filled with cerebrospinal fluid (CSF) (6). Some cysts remain asymptomatic while others may expand and cause symptomatic compression on surrounding structures. Symptoms depend greatly on location-whether over the sylvian fissure; over the cerebral convexity; in the interhemispheric region; in the sella and suprasellar region; around the optic nerve, the quadrigeminal plate, or the cerebellopontine angle; in the region of the clivus; over the cerebellar vermis or cerebellar hemisphere; or within the lateral or fourth ventricle.

With the advent of modern treatment techniques, debate continues regarding which surgical treatment is most effective $(1-3,5,9,10,11)$. Treatment options of arachnoid cysts include expectant management, cyst shunting, craniotomy for fenestrations, deviation of cyst fluid to another intracranial space, stereotactic aspiration and endoscopic fenestration. 
Previous studies suggested that variability in outcomes could be partially attributed to differences in operative technique (9).

We retrospectively report on consecutive series of patients with surgically treated arachnoid cysts in a single institution and gathered selection criteria of treatment.

\section{MATERIAL and METHODS}

\section{Patient selection:}

Institutional review board approval was obtained for the retrospective review of the patient records pertinent to the study. All patients were symptomatic and underwent surgery following consensus of the department faculty. Asymptomatic patients and the patients who were managed with observation only were excluded from the study. All patient records were reviewed, and symptoms at presentation, cyst location, age, cyst resolution, symptom resolution, follow-up periods and treatment modalities were recorded.

\section{RESULTS}

Patients: Between January 1992 and December 2009, 75 patients with intracranial arachnoid cysts underwent surgery in our department of neurosurgery. All diagnoses were confirmed on neuroimaging, during surgery and with histopathological examination. Included in the study were 54 male $(72 \%)$ and 21 female (28\%) patients, ranging in age from 2 months to 45 years (mean age 20.02 years) at the time of surgery.

Pediatric patients: 11 patients (14,6\%) were less than 16 years old. Two intracranial cysts were diagnosed in intrauterine ultrasonography (USG) examination. Patients did well after birth. During periodic follow-up, shifting on computed tomography (CT) images and intracranial pressure (ICP) elevation signs were noted in the first year of life. The patient with intraventricular arachnoid cyst underwent endoscopic cystoventriculostomy and other patient with an arachnoid cyst located at sylvian fissure underwent cystoperitoneal shunting.

Symptoms: Symptoms at presentation included headache (75\%), seizures $(26.1 \%)$, hydrocephalus $(10 \%)$, cognitive decline (10\%), weakness (10\%), and gait disturbance (15\%).

Follow-up: Overall postoperative follow-up ranged between 9 months and 6 years (mean 2.2 years). Follow-up of endoscopic operations ranged between 6 months and 24 months (mean 12 months). The follow-up of the patients were performed with regular CT scans in every three months in the first year following the operation. After the first year, annual CT scans were preferred.

Lesion Location: Sixty two of the cysts were supratentorial $(82,6 \%)$, and thirteen infratentorial $(17,4 \%)$ : Thirty eight in the sylvian fissure $(50,6 \%)$, ten in the temporal lobe (13.3\%), four in the intraventricular region (5,3\%), four in the suprasellar area $(5,3 \%)$, and five were located in the cerebral convexity (6.6\%).

\section{TREATMENT METHODS}

All procedures were performed after induction of general anesthesia. No seizure prophylaxis or corticosteroids were applied. All patients received intravenous antibiotic prophylaxis just before skin incisions. Neuronavigation system was not used. No fenestration was repeated and when fenestration failed shunting procedures were performed.

Endoscopic cyst treatment (20\%): Fifteen patients whose cysts were in close communication to basal cisterns or lateral ventricles were selected for endoscopic treatment. Endoscopic treatment was either cystoventriculostomy or cystocisternotomy. One in the intraventricular region diagnosed in intrauterine USG and underwent operation for cystoventriculostomy two months after birth, two in intraventricular region in adults underwent operation for cystoventriculostomy, ten in sylvian fissure underwent cystocisternotomy and two infratentorial cysts underwent cystocisternotomy.

Microscopic cyst wall excision (5,3\%): Four cerebral convexity arachnoid cysts underwent microscopic cyst wall excision (Figure 1A-F). Histopathological examination revealed "glioependymal cyst".

Microscopic cystocisternotomy (28\%): Twenty one patients underwent microscopic fenestration of the cysts into the basal cisterns. Seventeen were supratentorial and 4 infratentorial (Table I).

Shunting procedure as primary treatment (46,6\%): Thirty five patients underwent shunting procedure as primary treatment.

Shunting procedure following the failure of microscopic treatments (47.6\%): Ten of 21 patients underwent shunting procedure following remaining or recurrence symptoms following microscopic cystocisternotomy. Timing of shunting procedure following microscopic operations ranged between 1 and 14 months (mean 4.2 months).

Symptomatic improvement:: Headache was controlled in $92.5 \%$ of adult cases. Hydrocephalus, cognitive decline, weakness and gait disturbances were controlled $100 \%$ after overall treatment methods. All 17 patients with seizure problems had been treated with anticonvulsants and they were seizure free before the operations.

Follow-up CT scans showed significant reduction in cyst size in $83 \%$ of supratentorial arachnoid cysts.

Infratentorial arachnoid cysts: No significant changes in cyst size were found in infratentorial cysts but symptomatic improvements were noted (Figure 2A-F). All of microscopic treatments were followed by shunting due to symptom recurrence. In two patients symptomatic recurrences were seen one year following microscopic treatment. Overall 11 infratentorial arachnoid cysts underwent shunting procedures and 4 of them underwent shunt revision operations. 


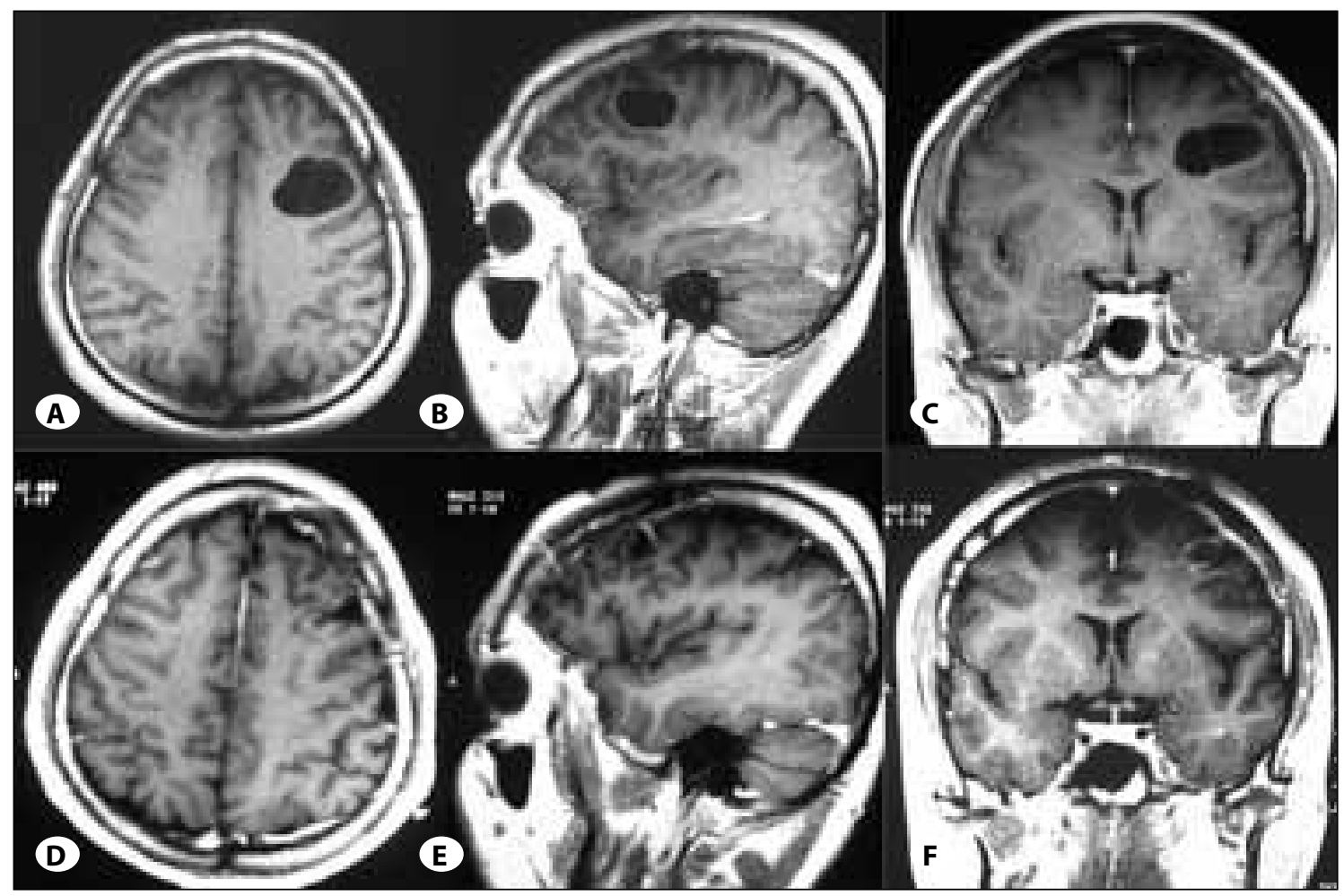

Figure 1: Preoperative axial (A), sagittal (B) and coronal (C) T1 Weighted MRI images of a left cerebral convexity arachnoid cyst is seen. D, E, F, Postoperative axial (D), sagittal (E) and coronal (F) T1 Weighted MRI images showing significant decrease in cyst size.

Table I: The Distribution of Treatment Methods Regarding the Cyst Localizations

\begin{tabular}{|c|c|c|c|c|c|c|c|}
\hline & Cyst location & Endoscopic & $\begin{array}{c}\text { Microscopic } \\
\text { cyst wall } \\
\text { resection }\end{array}$ & $\begin{array}{c}\text { Microscopic } \\
\text { cystocisternotomy }\end{array}$ & shunting & $\begin{array}{l}\text { Shunting } \\
\text { following } \\
\text { microscopic } \\
\text { op. }\end{array}$ & $\begin{array}{l}\text { Shunt } \\
\text { revision }\end{array}$ \\
\hline \multirow{5}{*}{$\begin{array}{l}\text { Supratentorial } \\
(62)\end{array}$} & Sylvian (38) & 10 & - & 10 & 18 & 4 & 6 \\
\hline & Temporal (10) & - & - & 3 & 7 & 2 & 1 \\
\hline & Intraventricular (5) & 3 & - & - & 2 & - & - \\
\hline & Suprasellar (4) & - & - & 4 & - & - & - \\
\hline & $\begin{array}{l}\text { Cerebral } \\
\text { convexity (5) }\end{array}$ & - & 4 & - & 1 & - & - \\
\hline $\begin{array}{l}\text { Infratentorial } \\
\text { (13) }\end{array}$ & Infratentorial (13) & 2 & - & 4 & 7 & 4 & 4 \\
\hline Total (75) & & $15(20 \%)$ & $4(5,3 \%)$ & $21(28 \%)$ & $35(46,6 \%)$ & 10 & $11(24,4 \%)$ \\
\hline
\end{tabular}

Complications: There was no operative mortality in our series.

Subdural hematoma: Two patients developed subdural hematoma postoperatively, which was operated and evacuated (Figure $3 \mathrm{~A}-\mathrm{C}$ ). Cause of bleeding was the bridging veins between the cyst wall, the dura and the cortex (Figure 4). Subdural hygroma: Four patients who underwent shunting procedure developed subdural hygromas. We have managed subdural hygromas only by observation. In the later follow-up controls these subdural hygromas were resolved (Figure 5).
Meningitis: One patient developed meningitis and was treated with appropriate antibiotics. CSF leak: Endoscopically operated three patients were treated for CSF leak. The patient whose intraventricular arachnoid cyst was diagnosed in intrauterine life and underwent endoscopic cystoventriculostomy needed an operation for dural repair due to CSF leak. Other two patients with CSF leak were adults and they were treated with tight head bandages for ten days.

Cranial nerve palsy: We observed slight slowing of eye lid opening due to excessive microscopic dissection of arachnoid 


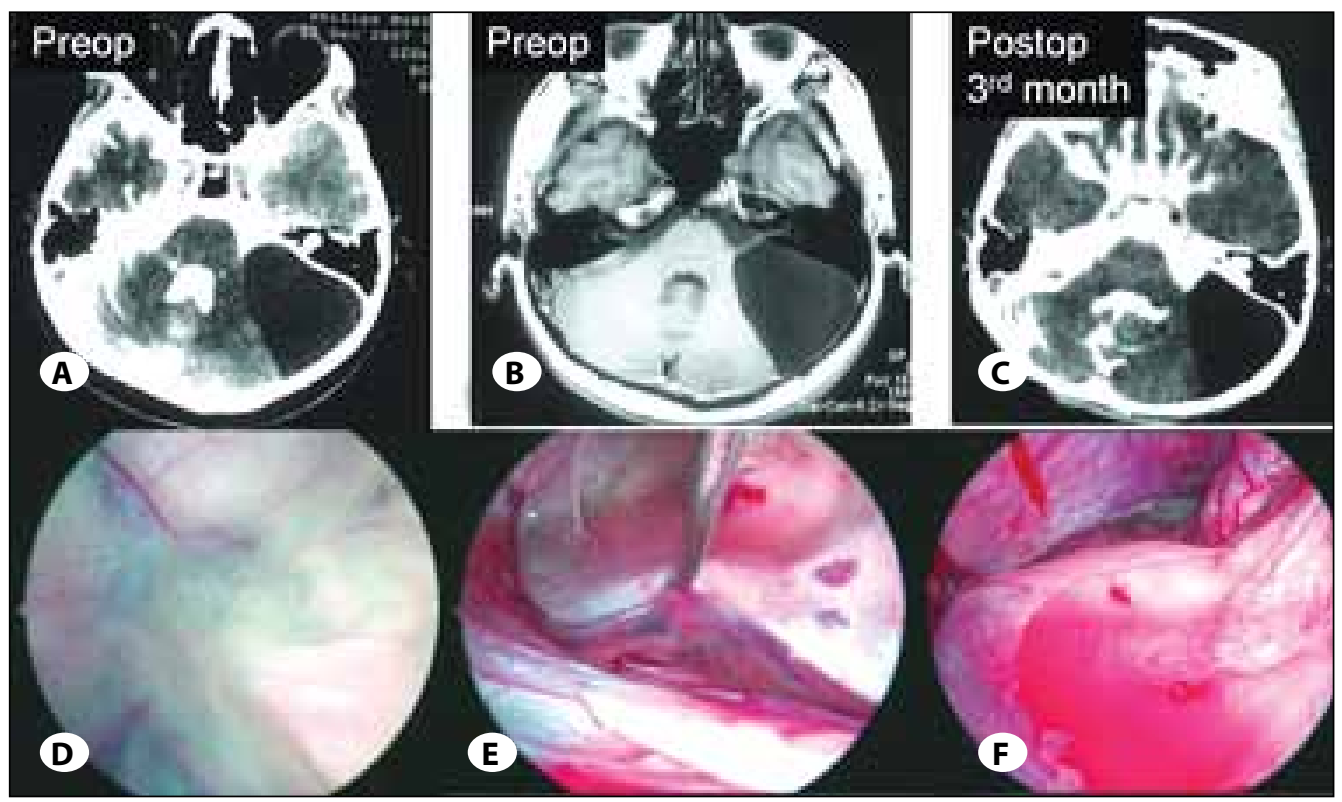

Figure 2: 20-year-old man. Preoperatively presented with headache and nausea. Patient underwent endoscopic cystocisternotomy operation. Preoperative and postoperative 3rd months $C T$ cisternography revealed no change $\mathbf{( A , B , C )}$ but patient is without symptoms under follow-up. Thick arachnoid membrane, arachnoid trabeculations and tough adhesion where the cranial nerve invaginates are seen $(\mathbf{D}, \mathbf{E}, \mathbf{F})$.

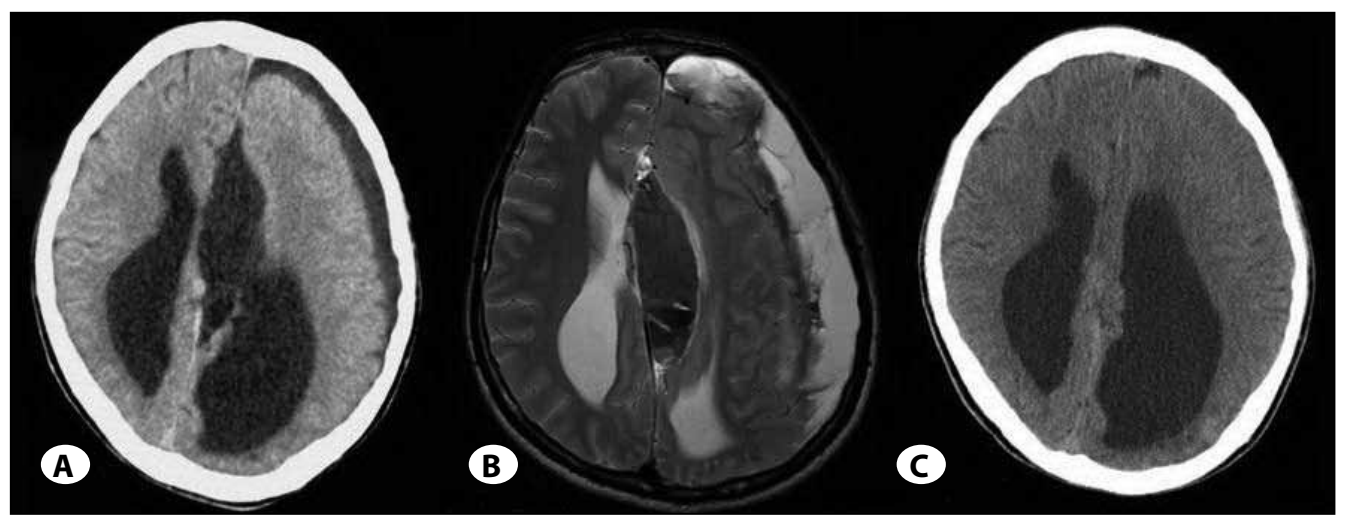

Figure 3: Preoperative image of the arachnoid cyst (A). Left parietal subdural hematoma following endoscopic cystoventricolostomy (B). Subdural hematoma was evacuated, cystoventriculostomy has successfully resolved the midline shift (C).

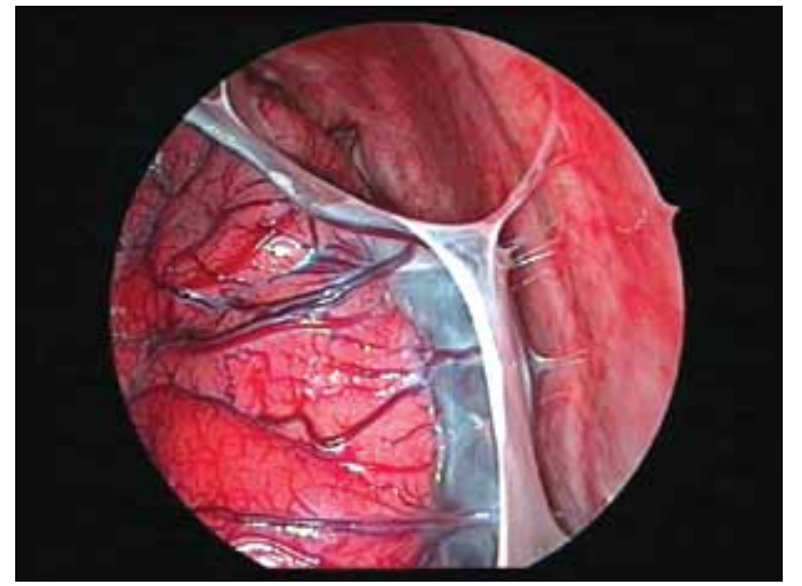

Figure 4: Bridging veins between cerebral cortex, dura and arachnoidal membranes. membranes covering third nerve in one patient. Dizziness: 20 of 54 adult patients suffered from dizziness for one to three months after operation.

Failure of macroscopic or endoscopic treatments (47.6\%): There was not any failure of endoscopic treatment in our series. We think that this is not because of superiority of endoscopic treatment but because of the relative minority of those patients in our series.

Shunt revisions: Overall, 45 patients (60\%) underwent shunt procedures including primary shunting and combined operations. 11 of 45 patients $(24,4 \%)$ underwent operations for shunt revision one or multiple times. 


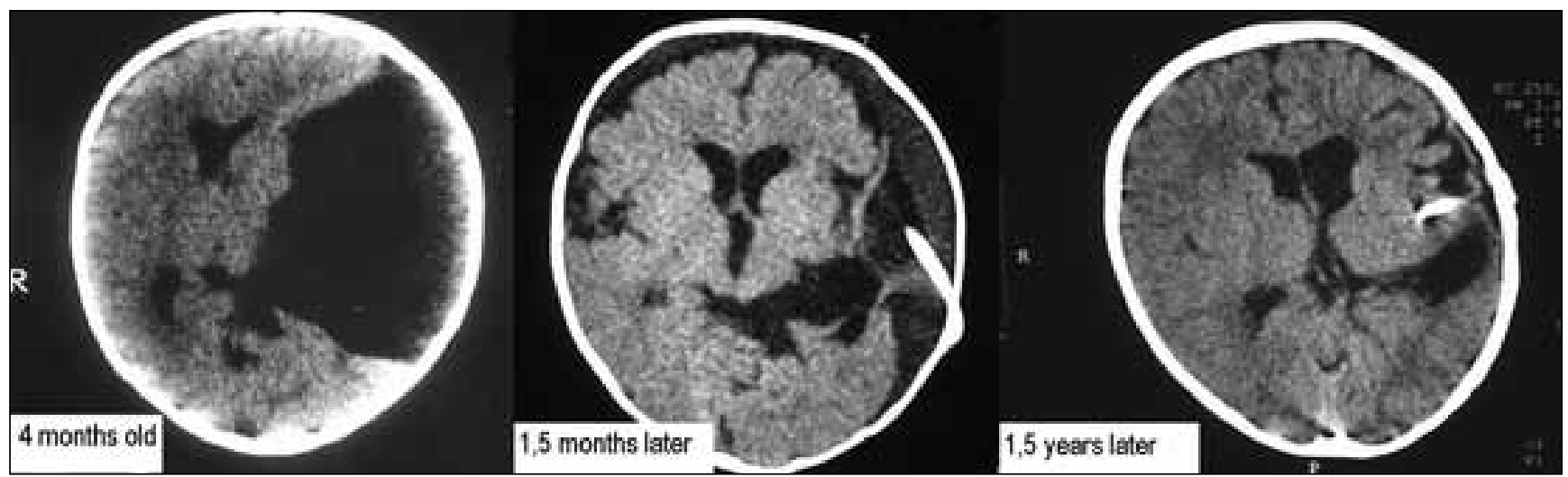

Figure 5: An intracranial cyst was diagnosed in intrauterine USG examination. Patient was well doing after birth. During periodically follow-up shifting at CT and ICP elevation signs were noted. Patient underwent cystoperitoneal shunting. 1,5 month after operation subdural hygroma was noted and managed with observation. 1,5 years after shunting procedure subdural hygroma was resolved.

\section{ILLUSTRATIVE CASES}

\section{Case 1}

60- year-old woman was incidentally diagnosed a right occipital arachnoid cyst. The patient was symptom free and underwent periodical follow-up for cyst progression annually for 10 years. Headache and gait disturbance gradually exacerbated 2 years prior to operation. Eventually after clearly showing the expansion of the cyst and attributing the symptoms to the cyst expansion, the benefits of the endoscopic cystoventriculostomy were discussed with the patient. Symptoms gradually resolved following the operation. Six months following the operation the cyst size was significantly reduced even in comparison with previous ten years.

Technique for endoscopic cyst fenestration (Endoscopic cystoventriculostomy): A burr was used for access, with the entry site determined by the region within which the arachnoid cyst was located. We opened the dura at the dome of the arachnoid cyst. A $4 \mathrm{~mm}, 0^{\circ}$ or $30^{\circ}$ rigid lens endoscope (Kar Storz ${ }^{\circ}$, Tutlingen, Germany) was used for the initial exploration. After exploring the intraarachnoidal space we inserted endoscopic instruments next to the endoscope in the burr hole. Once the target site has been selected, a bipolar diathermy instrument is used both to attenuate the tissue and to provide a blunt instrument to perforate the cyst wall. After a small communication between the cyst and the cistern or ventricle has been made, a progressive enlargement of the fenestration is created using a combination of blunt perforation, and sharp scissors to connect a series of smaller fenestrations and to maintain a large conduit for CSF egress. (Figure 6).

\section{Case 2}

22-year-old woman presented with headache. After evaluation of the patient, headache was attributed to the cyst and options of the surgical intervention were discussed with the patient. Eventually endoscopically cyst wall excision (cystocisternotomy) operation was performed. Cyst size progressively enchased and 5 months later temporal lobe was significantly enlarged (Figure 7 A,B). The patient's right eyelid was slightly slow in comparison with left. This was attributed to the extensive manipulation of the oculomotor nerve (Figure 7F).

Endoscopic cystocisternotomy: The arachnoid cysts located in the middle cranial fossa were selected for creation of a fenestration between the cyst and the basal cisterns. A 2-cm curvilinear incision was made behind the hairline from the root of the zygoma, extending superiorly. Muscle fiber separating dissection through the temporalis muscle was then performed, allowing placement of a self-retaining retractor. A burr hole was placed on the squamosal bone and $4 \mathrm{~mm}, 0^{\circ}$ or $30^{\circ}$ rigid lens endoscope (Karl Storz Tutlingen Germany) was used for the initial cannulation. After exploring the intraarachnoidal space we inserted endoscopic instruments next to the endoscope in the burr hole. Once the cyst is safely cannulated, the anatomy of the region dictates the performance of the distal fenestration. By advancing the endoscope along the sphenoid ridge, the internal carotid artery bifurcation and the ipsilateral optic nerve midcerebral artery, anterior cerebral artery, olfactory nerve and oculomotor nerve should be visible (Figure 7E, F). The membranes separating arachnoid cyst from basal cisterns are mostly heterogeneous in thickness (Figure 7D). Endoscopic fenestration and cyst wall resection should be started from the thinnest part by using blunt and sharp dissection techniques which we always use in microscopic operations. Cyst wall remnants separating the cyst and basal cisterns should be removed as much as possible in order to prevent recurrence. CSF pulsations, demonstrating free communication of the deep cisterns, confirm successful completion of the procedure. The wound was then filled with saline solution, and the dura was repaired with an onlay dura substitue. The temporalis muscle and scalp were then reapproximated with interrupted 3-0 absorbable polyglactin sutures, followed by running 4-0 nylon sutures. A cyst catheter 

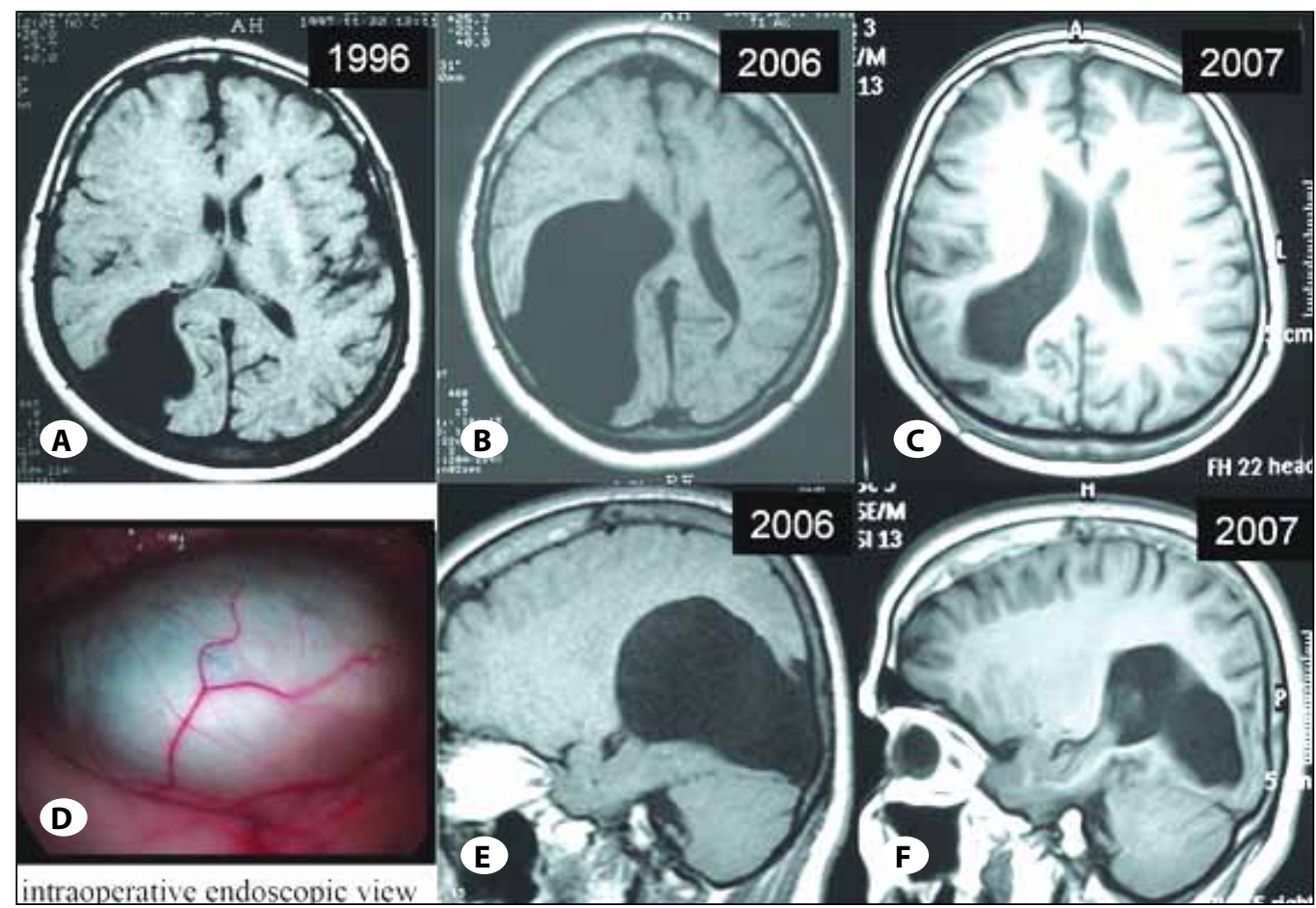

Figure 6: 60-year-old woman was incidentally diagnosed a right occipital arachnoid cyst. The patient was symptom free and underwent periodically follow-up for cyst progression yearly for 10 (ten) years A, B, C, E, F. The patient underwent operation in 2006 due to symptomatic expansion of the cyst. Six months following the operation the cyst size was significantly reduced even in comparison with previous ten years. Intraoperative endoscpoic view of the cyst wall is seen on $\mathbf{D}$.

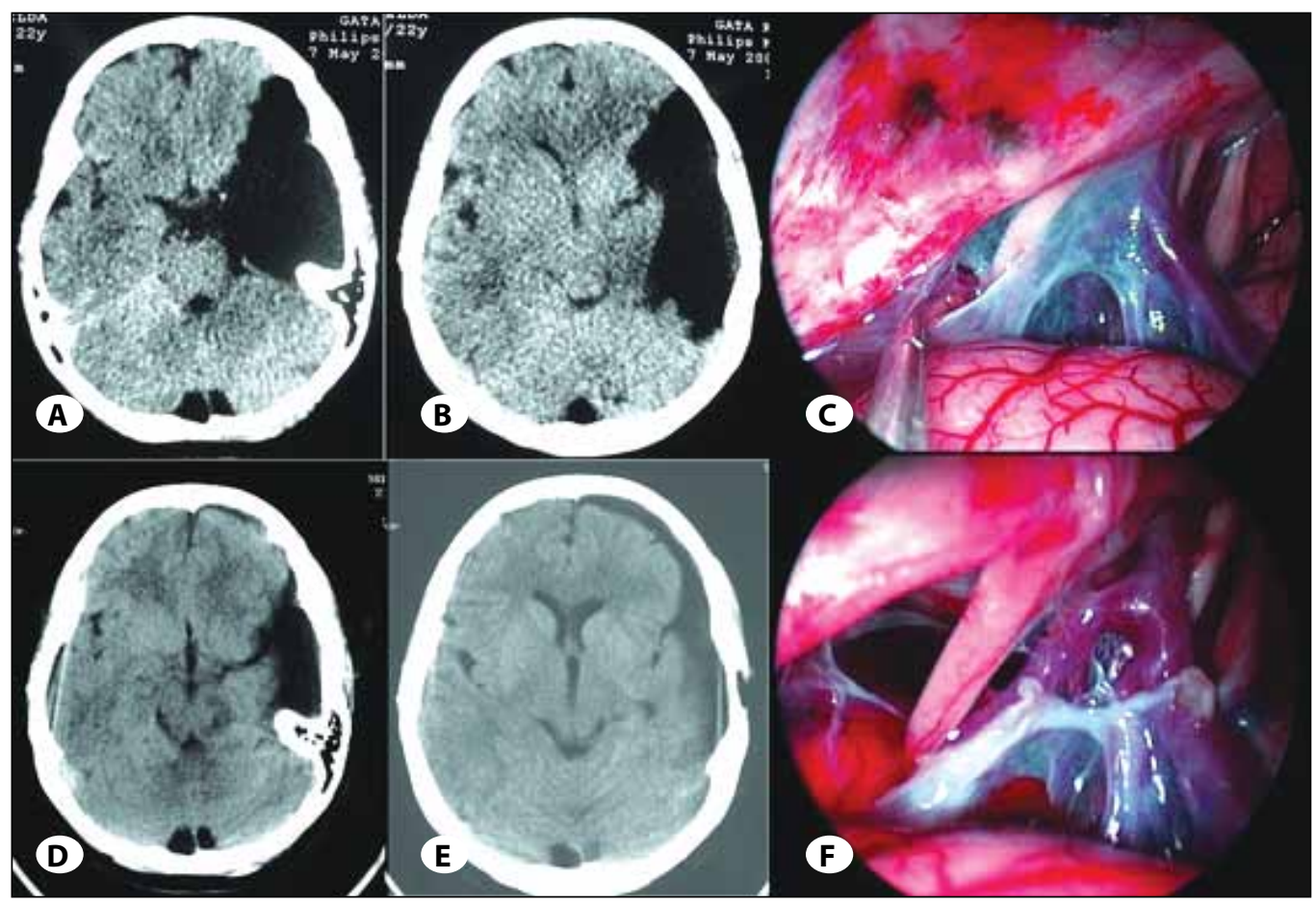

Figure 7: 22-year-old woman with left middle fossa arachnoid cyst. A. and B., Preoperative CT scans. C and E., Postoperative CT scans showing significant decrease in cyst size. C., Intraoperative endoscopic view of the membranes separating the basal cisterns and cyst cavity. F., Endoscopic view of the membranes at the end of the cystocisternotomy operation. By advancing the endoscope along the sphenoid ridge, the internal carotid artery bifurcation and the ipsilateral optic nerve middle cerebral artery, anterior cerebral artery, olfactory nerve and oculomotor nerve is visible. The membranes separating arachnoid cyst from basal cisterns mostly are heterogenous in thickness. 
was not routinely left in place after the procedure. Following extubation and transportation to the recovery room, patients had an overnight stay in the intensive care unit.

\section{DISCUSSION}

The best surgical management of intracranial arachnoid cysts remains controversial.

Extensive application of cranial investigation methods resulted in diagnosing of the intracranial arachnoid cysts incidentally. Management of the asymptomatic lesions also remains controversial somehow. In this report we reviewed arachnoid cysts with a focus on the surgical management and selection criteria for management. All authors agree that symptoms of intracranial hypertension (with or without hydrocephalus), intractable seizures, and focal neurological deficits warrant treatment $(1,4,6,7,12)$. Our selection criteria for management were age, symptomatic presentation, lesion location, and close communication with a ventricle or a cisternal compartment. During the time interval of this study we have performed cyst shunting, craniotomy for fenestration or cyst wall resection, and endoscopic fenestration.

\section{Selection for shunting:}

In our series we preferred shunting as standard treatment in patients younger than 1 year old except one case who underwent endoscopic cystoventriculostomy (Figure 5) Our second indication for shunting was recurrent or symptomatically persistent arachnoid cysts following other treatment modalities, regardless of age.

Arai et al. presented their results of treatment with cystoperitoneal (CP) shunting of 77 patients with middle fossa arachnoid cysts. In their series they treated 20 asymptomatic patients (2). CP shunting is minimally invasive and achieves a high rate of resolution on neuroimaging. However, in the absence of definite symptoms, shunting should be reconsidered, because of shunt dependency. Kim et al reported this risk of shunt dependency in patients with arachnoid cysts treated with CP shunting (8). At the first half of this study period authors preferred shunting as the first line of treatment. Later on regarding the dependency and the improvement of novel techniques we have reconsidered the treatment options. In the later period, we avoided shunt placement as the first treatment option.

\section{Selection for microscopic cyst wall resection:}

If an arachnoid cyst is located in the cerebral convexity and has displaced brain structures or is symptomatic at the time of presentation, we prefer microscopic cyst wall resection as much as possible. Most of these lesions are of a special kind of arachnoid cyst formation consisting of a luminal epithelial layer connected with a glial sheet, followed peripherally by a thin connective tissue covering. The glial nature of parts of the cyst lining can be shown by glial fibrillary acidic protein staining. Some authors have referred to these cysts as "glioependymal" (6). Four cerebral convexity arachnoid cysts underwent microscopic cyst wall excision in our series and the results were excellent. We have not experienced any recurrence or need for shunting (Table I).

\section{Endoscopic cyst wall excision (cystoventriculostomy or cystocisternotomy):}

Patients with a cyst in close communication with a ventricle or a cisternal compartment are candidates of establishing an effective fenestration either endoscopically or microscopically. In our series we have not performed our endoscopic operations via a working channel. Instead, we used the burr hole as our working channel. The displacement of adjacent structures by the cyst provides a wide corridor through which the deep anatomic structures can be observed and accessed without brain retraction. (Figure 7D, F). Greenfield et al. presented a series of 33 patients treated endoscopically or with endoscopically assisted cyst fenestration in 2005 (5). They have reported 96.9\% successful fenestration with an excellent rate of long-term patency. They have beautifully presented the methods of endoscopic cyst fenestration. Our series was consisted of six patients and was quite heterogeneous. We have described our methods of cystoventriculostomy or cystocisternotomy in details. We achieved $100 \%$ success rate by means of fenestration. We can say that it is possible to perform successful fenestration but due to the small number of patients in our series we were unable to compare our results with microscopic operations. We think that endoscopic operations are cosmetically more acceptable, and postoperative recovery time is shorter than microscopic operations, but common difficulties of working with endoscope ie. lack of 3D vision, and the need for specially produced hand instrument should be remembered.

Infratentorial arachnoid cyst: We observed that the cyst size does not significantly change even after extensive marsupialization of the cyst wall with microsurgical techniques, microscopic or endoscopic fenestration and shunting procedure in infratentorial arachnoid cysts in our series. But the symptoms of the patients resolved. The arachnoid membranes are noted to be thicker and more adherent where arteries pass through the wall of one cisternal compartment to join another. These tough adhesions are also present at the point where the cranial nerve invaginates the arachnoid, and it is usually not possible to remove all the arachnoid septations without undue risk of injury to the traversing lower cranial nerves. Consequently response to surgery may be short lived, with reformation of the cyst within weeks of operation. (13). Mostly posterior fossa arachnoid cysts underwent shunting procedures following cystocisternotomy. In our series, all microscopic cystocisternotomy operations eventually needed shunting procedures except two endoscopic operations. We think that this may not be because of the superiority of the endoscopic procedure but due to the short follow-up of endoscopic operated patients in our present series. If the patients who underwent endoscopic cystocisternotomy present to us again with the same symptoms we will choose the shunting procedure. 


\section{CONCLUSION}

Advancing technology provides new treatment options for arachnoid cysts. Patients with symptomatic arachnoid cysts regardless of age and cyst location should be treated. The neurosurgeon should keep in mind that there is a list of treatment options and the best treatment option may be selected after discussing all options with the patient. Avoiding shunt dependency should be one of the principle goals of treatment. Appropriate patient and treatment selection results in excellent outcomes.

\section{REFERENCES}

1. Alexiou GA, Varela M, Sfakianos G, Prodromou N: Shunting for the treatment of arachnoid cysts in children. Neurosurgery 67(6):1632-1636, discussion 1636, 2010

2. Arai $H$, Sato $K$, Wachi A, Okuda O, Takeda N: Arachnoid cysts of the middle cranial fossa: Experience with 77 patients who were treated with cystoperitoneal shunting. Neurosurgery 39(6):1108-1113, 1996

3. Ciricillo SF, Cogen PH, Harsh GR, Edwards MS: Intracranial arachnoid cysts in children. A comparison of the effects of fenestration and shunting. J Neurosurg 74:230-235, 1991

4. Daneyemez M, Gezen F, Akbörü M, Sirin S, Ocal E: Presentation and management of supratentorial and infratentorial arachnoid cysts. Review of 25 cases. J Neurosurg Sci 43(2): 115-121, discussion 122-123, 1999

5. Greenfield JP, Souweidane MM: Endoscopic management of intracranial cysts. Neurosurg Focus 19(6):E7, 2005
6. Hellwig D, Schulte M, Tirakotai W: Surgical management of Arachnoid, suprasellar, and rathke's cleft cysts, in Schmidek $\mathrm{HH}$, Roberts DW (eds), Schmidek \& Sweet Operative Neurosurgical Techniques, 5th ed, vol 1: Saunders Elsevier, 2006: $\quad 455-476$

7. Hoffman HJ, Hendrick EB, Humphreys RP, Armstrong EA: Investigation and management of suprasellar arachnoid cysts. J Neurosurg 57(5): 597-602, 1982

8. Kim SK, Cho BK, Chung YN, Kim HS, Wang KC: Shunt dependency in shunted arachnoid cyst: $A$ reason to avoid shunting. Pediatr Neurosurg 37(4):178-185, 2002

9. Levy ML, Wang M, Aryan HE, Yoo K, Meltzer H: Microsurgical keyhole approach for middle fossa arachnoid cyst fenestration. Neurosurgery 53(5):1138-1144, discussion 1144-1145, 2003

10. Secer HI, Duz B, Solmaz I, Gonul E: Endoscopic clipping of a middle cerebral artery aneurysm in a middle fossa arachnoid cyst and review of the literature. Minim Invasive Neurosurg 53(3):132-137, 2010

11. Sommer IE, Smit LM: Congenital supratentorial arachnoidal and giant cysts in children: A clinical study with arguments for a conservative approach. Childs Nerv Syst 13:8-12, 1997

12. Stein SC: Intracranial developmental cysts in children treatment by cystoperitoneal shunting. Neurosurgery 8: 647-650, 1981

13. Venes J, Brunbeg J: Cysts. In Apuzzo MJ (ed) Brain Surgery: Complication avoidance and management, 1 st ed, vol:2. Churchill Livingstone Inc., 1993:2003-2021 